Article

\title{
Integrated Utilization of Sewage Sludge and Coal Gangue for Cement Clinker Products: Promoting Tricalcium Silicate Formation and Trace Elements Immobilization
}

\author{
Zhenzhou Yang ${ }^{1}$, Yingyi Zhang ${ }^{1}$, Lili Liu ${ }^{1}$, Seshadri Seetharaman ${ }^{2}$, Xidong Wang ${ }^{1}$ and \\ Zuotai Zhang 1,3,* \\ 1 Beijing Key Laboratory for Solid Waste Utilization and Management and Department of Energy and \\ Resource Engineering, College of Engineering, Peking University, Beijing 100871, China; \\ zgkdyzz@126.com (Z.Y.); zhyingyi2@163.com (Y.Z.); liu-0806@163.com (L.L.); xidong@pku.edu.cn (X.W.) \\ 2 Department of Materials Science Engineering, Royal Institute of Technology, Stockholm SE 100-4, Sweden; \\ raman@kth.se \\ 3 School of Environmental Science and Engineering, South University of Science and Technology of China, \\ Shenzhen 518055, China \\ * Correspondence: zuotaizhang@pku.edu.cn; Tel.: +86-10-8252-4800; Fax: +86-10-6275-6623
}

Academic Editor: Jorge de Brito

Received: 6 December 2015; Accepted: 30 March 2016; Published: 7 April 2016

\begin{abstract}
The present study firstly proposed a method of integrated utilization of sewage sludge (SS) and coal gangue (CG), two waste products, for cement clinker products with the aim of heat recovery and environment protection. The results demonstrated that the incremental amounts of SS and CG addition was favorable for the formation of tricalcium silicate $\left(C_{3} S\right)$ during the calcinations, but excess amount of SS addition could cause the impediment effect on $\mathrm{C}_{3} \mathrm{~S}$ formation. Furthermore, it was also observed that the $\mathrm{C}_{3} \mathrm{~S}$ polymorphs showed the transition from rhombohedral to monoclinic structure as SS addition was increased to $15 \mathrm{wt} \%$. During the calcinations, most of trace elements could be immobilized especially $\mathrm{Zn}$ and cannot be easily leached out. Given the encouraging results in the present study, the co-process of sewage sludge and coal gangue in the cement kiln can be expected with a higher quality of cement products and minimum pollution to the environment.
\end{abstract}

Keywords: waste; sewage sludge; coal gangue; eco-cement; clinker; trace element

\section{Introduction}

With the rapid development of urbanization and industrialization, various solid wastes accumulate year by year, not only occupying land but also causing serious environment problems. Traditional waste disposal methods, such as pile up or landfill, have proven to be of low efficiency, a waste of resources and even environmentally harmful. The increasing shortage of resources and the negative impact on the environment, seen from a global perspective motivated the present work with respect to finding efficient process route toward waste utilization.

Among these solid wastes, sewage sludge (SS) and coal gangue (CG) are two typical common wastes generated. Sewage sludge is a problematic waste generated from wastewater treatment. The production of dried SS in China is currently eight million tons per year and is still increasing at a rate between $8 \%$ and $10 \%$ annually [1]. Due to the high content of hazardous substances such as organic, non-biodegradable compounds, bacteria and viruses, etc., the improper disposal of SS could pollute the environment severely. The most common treatment methods in China are agricultural utilization, landfilling, and incineration [2-4]. However, the reduced availability of land and the presence of pathogens and contaminants such as heavy metals, micro-pollutants, and antimicrobial 
agents limit applications of these methods. Coal gangue, as one of the common industrial wastes, is one of the main byproduct from coalmining and beneficiation and accounts for about $15-20 \mathrm{wt} \%$ of coal production [5-7]. CG stockpiles have reached 4.5 billion tons in China and are increasing at the speed of 750 million tons per year. The traditional disposal method of accumulation is also infeasible due to increasingly stringent environmental regulations. Thus, an environment-friendly and economically viable process to jointly dispose of these two wastes is urgently required.

Cement kiln is well known as an ideal device to dispose wastes, which can completely decompose the hazardous substance such as dioxins and furans due to the high temperature and long residual time [8]. Based on the characteristics of SS and CG, these two wastes may be utilized in the cement kiln for clinker production, where the organic matter can serve as an alternative fuel and the residual inorganic ash can be incorporated into clinker as part of raw materials. Thus, the use of SS or CG in cement kiln offers multiple advantages such as reduced use of primary raw materials, lower fuel consumption and significant reduction in $\mathrm{CO}_{2}$ emission. Besides, this integrated activity can also produce additional revenue to subsidize government waste disposal.

A number of investigations have been carried out with a view to utilize SS as a replacement for some raw materials used in cement manufacturing [9-12]. The main focus in the case of most of these studies has been the impact of SS on the properties of cement such as setting time and compressive strength. However, very few investigations have been conducted on how to combine cement plant with CG and SS disposal and their effect on the clinker properties, such as crystalline structure and crystal formation mechanism when they substitute a part of the raw materials for manufacturing of clinkers. Furthermore, due to the increased public concern with environment risk, it is important to evaluate the effect on the environment during the process of utilization of SS and CG, especially the trace element problem. It is well known that the interphase in the clinker has a high capacity to immobilize trace elements due to its specific structure and the silicate phases can also stabilize trace elements through solid solution $[13,14]$. In addition, the clay minerals in CG can help stabilize trace elements during calcinations. Therefore, the co-process of SS and CG in cement kiln can be expected to be a promising method for environmental protection. To the best of the knowledge of the present authors, the quantitative analysis of trace elements immobilizing into clinkers during the co-process of SS and CG has not been systematically investigated.

In this regard, the aim of these studies is to compare the characteristics of eco-cement clinker (made with SS and CG substitution) with ordinary cement clinkers synthesized in laboratory environment. The formation mechanism, crystalline phase components and structure, and crystalline micrographs were investigated in this study. The distribution behavior of trace elements during eco-clinker production was also studied. Further, the energy and raw materials consumptions were also evaluated. The present studies are expected to provide a method of integrated utilization of SS and CG in cement industry, which can save energy and resources, and improve trace elements immobilization at the same time.

\section{Experimental Section}

\subsection{Materials Characterization}

The dried sewage sludge pellet and coal gangue samples were collected from a municipal wastewater treatment plant located in Beijing, China. Coal gangue was supplied by power generation plant of Pingshuo in Shanxi Province, China. The results of proximate and ultimate analysis of SS and CG are shown in Table 1. As can be seen, SS had lower ash yield and fixed carbon content than that of CG, whereas it had higher volatile matter contents. The contents of sulfur in CG and SS are at low level, which can effectively increase the amount of liquid phase, resulting in decreasing the melting temperature point and its viscosity. The formation of $\mathrm{C}_{3} \mathrm{~S}$ might therefore be accelerated. Furthermore, the calorific value of SS was around $9.35 \mathrm{MJ} / \mathrm{kg}$, which was higher than that of CG (4.82 MJ/kg). 
Table 1. Chemical compositions of coal gangue and sewage sludge.

\begin{tabular}{|c|c|c|c|c|c|c|c|c|c|c|c|}
\hline \multicolumn{6}{|c|}{$\begin{array}{l}\text { Proximate Analysis } \\
\text { (wt \%) }\end{array}$} & \multicolumn{4}{|c|}{$\begin{array}{l}\text { Ultimate Analysis } \\
\text { (wt \%) }\end{array}$} & \multicolumn{2}{|c|}{$\begin{array}{c}\text { Calorific Value } \\
(\mathrm{MJ} / \mathrm{kg})\end{array}$} \\
\hline- & $\begin{array}{l}\text { moisture, } \\
\text { ad }^{\text {a }}\end{array}$ & $\begin{array}{l}\text { ash, } \\
\text { ad }^{a}\end{array}$ & $\begin{array}{c}\text { volatile } \\
\text { matter, ad a }\end{array}$ & $\begin{array}{c}\text { fixed } \\
\text { carbon, } \mathrm{ad}^{\mathrm{a}}\end{array}$ & Total & C, ad & $\mathrm{H}, \mathrm{ad}$ & $\mathrm{N}, \mathrm{ad}$ & $\mathrm{S}, \mathrm{ad}$ & & \\
\hline CG & 0.8 & 67.9 & 15 & 16.3 & 100 & 17.5 & 12.6 & 0.6 & 1.2 & & \\
\hline SS & 2 & 53.3 & 35.8 & 8.9 & 100 & 23.2 & 4.0 & 3.0 & 1.3 & & \\
\hline \multicolumn{12}{|c|}{ Chemical Composition (wt \%) } \\
\hline- & $\mathrm{SiO}_{2}$ & $\mathrm{Al}_{2} \mathrm{O}_{3}$ & $\mathrm{Fe}_{2} \mathrm{O}_{3}$ & $\mathrm{CaO}$ & $\mathrm{MgO}$ & $\mathrm{K}_{2} \mathrm{O}$ & $\mathrm{Na}_{2} \mathrm{O}$ & $\mathrm{P}_{2} \mathrm{O}_{5}$ & Others & LOI & Total \\
\hline CG & 32.8 & 28.8 & 1.2 & 0.1 & $<0.1$ & 0.1 & $<0.1$ & 0.1 & 2.5 & 34.4 & 100 \\
\hline SS & 25.2 & 5.6 & 4.2 & 6.4 & 1.5 & 1.2 & 0.6 & 4.9 & 1.4 & 48.6 & 100 \\
\hline \multicolumn{12}{|c|}{ Trace Elements Contents (mg/kg) } \\
\hline- & As & $\mathrm{Ba}$ & $\mathrm{Cd}$ & Co & $\mathrm{Cr}$ & $\mathrm{Cu}$ & $\mathrm{Mn}$ & $\mathrm{Ni}$ & $\mathrm{Pb}$ & \multicolumn{2}{|c|}{$\mathrm{Zn}$} \\
\hline CG & 19 & ND & ND & 8 & 25 & 15 & 6 & 4 & 9 & \multicolumn{2}{|c|}{14} \\
\hline SS & 50 & 256 & 2 & 11 & 124 & 358 & 543 & 41 & 48 & \multicolumn{2}{|c|}{1084} \\
\hline
\end{tabular}

The chemical compositions were determined by an X-ray fluorescence spectrometer (XRF, S4-Explorer, Bruker, Karlsruhe, Germany). The XRF analysis of SS and CG are also present in Table 1. It can be seen that the major components of SS and CG are $\mathrm{SiO}_{2}, \mathrm{Al}_{2} \mathrm{O}_{3}, \mathrm{Fe}_{2} \mathrm{O}_{3}$ and $\mathrm{CaO}$, which is the major components to prepare cement clinker. Besides, SS contains high amounts of alkalis and alkaline earth metal elements. It also should be noted that phosphorus levels in SS are much higher than that in CG. The concentrations of trace elements in SS and CG are also shown in Table 1. It can be seen that the trace elements in SS are notably higher than those in CG, especially $\mathrm{Zn}$ and $\mathrm{Cu}$.

To understand the structure of solid waste, the SS and CG were analyzed by X-ray diffraction (XRD, D/Max 2500, Rigaku, Tokyo, Japan) and Fourier transformation infrared (FT-IR) and the results are shown in Figure 1. It can be seen from Figure 1a that the major mineral phases in SS are quartz and calcite. In addition, anorthite was also identified in the SS. The XRD patterns of CG show the distinctive peaks belonging to the characteristics of kaolinite. Besides, the mineral phases of clinochlore was also identified in the CG. The FT-IR spectra of SS and CG are presented in Figure 1b. As for SS, the peaks at $3404,2923,2854,1439,2353$, and $1652 \mathrm{~cm}^{-1}$ are related to the organic function groups. This indicated the presence of high content of organic material such as carboxylic, alcoholic and amide compounds [15]. The high content of organic material likely lead to a high calorific value of SS compared to that of CG. Besides, the peaks at 1420 and $873 \mathrm{~cm}^{-1}$ indicate the existence calcite, while the peaks at 1010, 920,750, 660, 530 and $462 \mathrm{~cm}^{-1}$ are the characteristic bands of anorthite [16]. As for CG, the peaks at $3694,3669,3653,3620,1115,1100,1034,1009,934,912,792,754,540$ and $431 \mathrm{~cm}^{-1}$ are the characteristic bands of kaolinite while the peak at 3620, 1085, 1630, 1009, 655 and $460 \mathrm{~cm}^{-1}$ belong to the characteristics of clinochlore [16,17]. Furthremore, the peaks at 1080, 798, 690 and $462 \mathrm{~cm}^{-1}$ indicate the existence of quartz in CG and SS [16]. It can be seen that a strong band at $1033 \mathrm{~cm}^{-1}$ can be found in the spectra of CG and SS. For CG, this band belong to the $\mathrm{Si}-\mathrm{O}$ stretching of $\mathrm{Si}-\mathrm{O}-\mathrm{Si}$ while for $\mathrm{SS}$, it might be attributed to the $\mathrm{O}-\mathrm{H}$ in mineral components or the existence of $\mathrm{C}-\mathrm{O}$ function group $[18,19]$. 

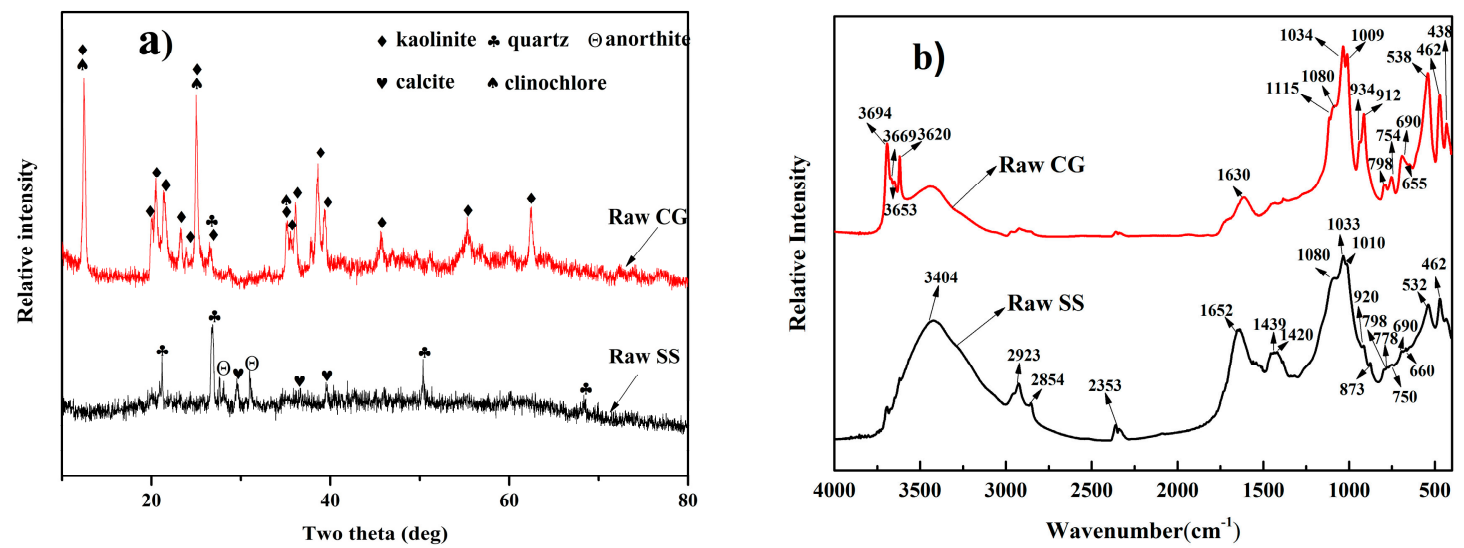

Figure 1. The X-ray diffraction (XRD) patterns and Fourier transformation infrared (FT-IR) spectra of raw coal gangue (CG) and sewage sludge (SS): (a) XRD patterns; and (b) FTIR spectra.

The thermal analyzer (Q600SDT, TA Instuments, New Castle, PA, USA) was used to study the thermal behavior of SS and CG. The measurements were conducted from ambient temperature to $1200{ }^{\circ} \mathrm{C}$ at a linear heating rate of $10^{\circ} \mathrm{C} / \mathrm{min}$ under air as atmosphere and the results are shown in Figure 2. It could be seen that the most rapid mass loss occurred at around $200{ }^{\circ} \mathrm{C}$ and two distinct peaks appeared in the derivative thermogravimetric (DTG) and differential scanning calorimetric (DSC) curves of SS. The former peak $\left(200\right.$ to $\left.370^{\circ} \mathrm{C}\right)$ was attributed to the combustion of volatiles and the second peak ( 370 to $500{ }^{\circ} \mathrm{C}$ ) corresponds to the char oxidation. On the contrary, the CG showed a different thermal behavior: rapid mass loss occurred in the temperature range between 400 and $600{ }^{\circ} \mathrm{C}$. The DTG and DSC curves showed only one distinct peak. It could also be noted that the spontaneous combustion did not occur until the temperature exceeded $200^{\circ} \mathrm{C}$. This suggested that the SS and CG can easily be stored and handled, without any risk of potential explosion from spontaneous combustion during the manufacturing process when using SS and CG as raw materials [20].

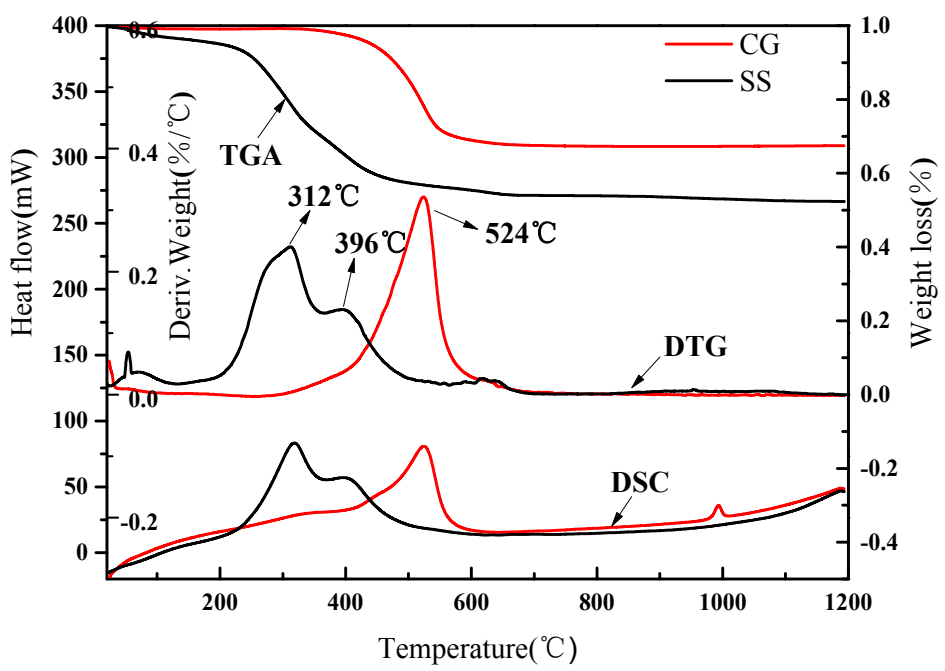

Figure 2. The thermogravimetric (TG), derivative thermogravimetric (DTG) and differential scanning calorimetric (DSC) curves of raw materials.

\subsection{Eco-Cement Clinkers Preparation}

The raw meals (raw materials to prepare for clinker) were prepared by mixing $\mathrm{CaCO}_{3}, \mathrm{SiO}_{2}$, $\mathrm{Al}_{2} \mathrm{O}_{3}, \mathrm{Fe}_{2} \mathrm{O}_{3}$ and various amounts of SS or CG. All the reagents used here were of analytical reagent grade. The compositional parameters in cement chemistry are listed as Equations (S1)-(S4). 
The raw meals were dried in air at $105^{\circ} \mathrm{C}$ for $24 \mathrm{~h}$ and ground in a ball mill until the particles can pass through \#200 mesh metallic sieve. Then, they were prepared under different blending ratios with SS additions of 5,10,15 and $30 \mathrm{wt} \%$, respectively. In consideration of cement clinker parameters, the mixing ratio of CG was chosen as 5 and $10 \mathrm{wt} \%$, as shown in Table 2. All the mixture were pressed to $\$ 20 \mathrm{~mm} \times 5 \mathrm{~mm}$ slices by applying a pressure of $10 \mathrm{Mpa}$ and calcined in the programmable electrically heated tube furnace. The furnace temperature was raised at the rate of $10^{\circ} \mathrm{C} / \mathrm{min}$ from room temperature to $1450{ }^{\circ} \mathrm{C}$. The temperature was maintained at $950{ }^{\circ} \mathrm{C}$ for $30 \mathrm{~min}$ to ensure the complete decomposition of $\mathrm{CaCO}_{3}$ and held at $1450{ }^{\circ} \mathrm{C}$ for $2 \mathrm{~h}$. After calcination, the eco-cement clinkers were cooled rapidly in air and pulverized to pass through \#200 mesh metallic sieve. The samples were collected for XRD, FTIR, and scanning electron microscope (SEM, S4800, Hitachi Ltd., Tokyo, Japan) analyses and the particle size distribution of raw meals are shown in Figure S1.

Table 2. The addition amount of sewage sludge and coal gangue in raw meal.

\begin{tabular}{ccc}
\hline \multirow{2}{*}{ Sample } & \multicolumn{2}{c}{ Addition Amount (\%) } \\
\cline { 2 - 3 } & SS & CG \\
\hline S1(Blank sample) & 0 & 0 \\
S2 & 5 & 0 \\
S3 & 10 & 0 \\
S4 & 15 & 0 \\
S5 & 30 & 0 \\
S6 & 0 & 5 \\
S7 & 0 & 10 \\
S8 & 15 & 5 \\
\hline
\end{tabular}

\subsection{Trace Element Immobilized Characterization}

In order to investigate the transformation behavior of trace elements during calcinations, the samples were digested in microwave assisted digestion system (EXCEL, TOPEX, PreeKem, Shanghai, China) in triple acid $\left(\mathrm{HNO}_{3}: \mathrm{HF}: \mathrm{H}_{3} \mathrm{PO}_{4}=4: 2: 1\right)$. The concentrations of selected trace elements $\mathrm{As}, \mathrm{Cd}, \mathrm{Co}, \mathrm{Cr}, \mathrm{Cu}, \mathrm{Ni}, \mathrm{Pb}$ and $\mathrm{Zn}$ were measured by inductively coupled plasma-atomic emission spectroscopy (ICP-AES, Prodigy XP, Leeman, Hudson, NY, USA). Standard reference materials GBW08401 (coal fly ash) [17] and GBW07406 (GSS-6, soil) [21] were used for calibration. The accuracy for the trace elements was within $\pm 10 \%$.

In order to determine the potential leachability of trace elements in clinkers, Toxicity Characteristic Leaching Procedure (TCLP) method of the US Environmental Protection Agency (US-EPA) was applied to the clinker. The extracting solution used was $0.1 \mathrm{M}$ acetic acid at $\mathrm{pH} 4.93$ and the trace elements in leachate were determined by ICP-AES.

\section{Results and Discussion}

\subsection{Mineralogical Characterization of the Eco-Cement Clinker}

The XRD patterns of eco-cement clinker with different amounts of SS addition are shown in Figure 3a. It can be seen that the major components of eco-cement clinkers are $\mathrm{C}_{3} \mathrm{~S}\left(\mathrm{Ca}_{3} \mathrm{SiO}_{5}\right)$, $\mathrm{C}_{2} \mathrm{~S}\left(\mathrm{Ca}_{2} \mathrm{SiO}_{4}\right), \mathrm{C}_{3} \mathrm{~A}\left(\mathrm{Ca}_{3} \mathrm{Al}_{2} \mathrm{O}_{6}\right.$ and $\left.\mathrm{Ca}_{3}(\mathrm{Al}, \mathrm{Fe})_{2} \mathrm{O}_{6}\right)$ and $\mathrm{C}_{4} \mathrm{AF}\left(\mathrm{Ca}_{4} \mathrm{Fe}_{2} \mathrm{Al}_{2} \mathrm{O}_{10}\right)$. Thus, the synthesized eco-cement clinkers exhibit the characteristics similar to those of ordinary Portland cement. Amongst these components, $\mathrm{C}_{3} \mathrm{~S}$ is the major component of Portland cement clinker that determines its quality. The most important characteristic peaks of $C_{3} S$ appeared at $2 \theta$ of about $32^{\circ}$ and the intensity of peak that is indicative of the relative contents of $C_{3} S$ in the clinker [22,23] (see Figure 3b). It should be noted that the characteristic peak of $\mathrm{C}_{3} \mathrm{~S}$ shows no significant changes with SS addition up to $10 \mathrm{wt} \%$. With further increasing SS addition, the intensity of diffraction peak of $\mathrm{C}_{3} \mathrm{~S}$ is found to increase significantly, indicating the positive effect on the formation of $C_{3} S$. However, the $C_{3} S$ diffraction peak dropped 
sharply with higher SS additions of up to $30 \mathrm{wt} \%$ and the phases of $\mathrm{f}-\mathrm{CaO}$ and $\mathrm{C}_{2} \mathrm{~S}-0.05 \mathrm{C}_{3} \mathrm{P}_{2}\left(\mathrm{Ca}_{3}\left(\mathrm{PO}_{4}\right)_{2}\right)$ are formed. These results indicate that appropriate amount of $\mathrm{SS}$ addition is favorable for the formation of $\mathrm{C}_{3} \mathrm{~S}$, while excessive SS addition shows the opposite effect on the formation of $\mathrm{C}_{3} \mathrm{~S}$.
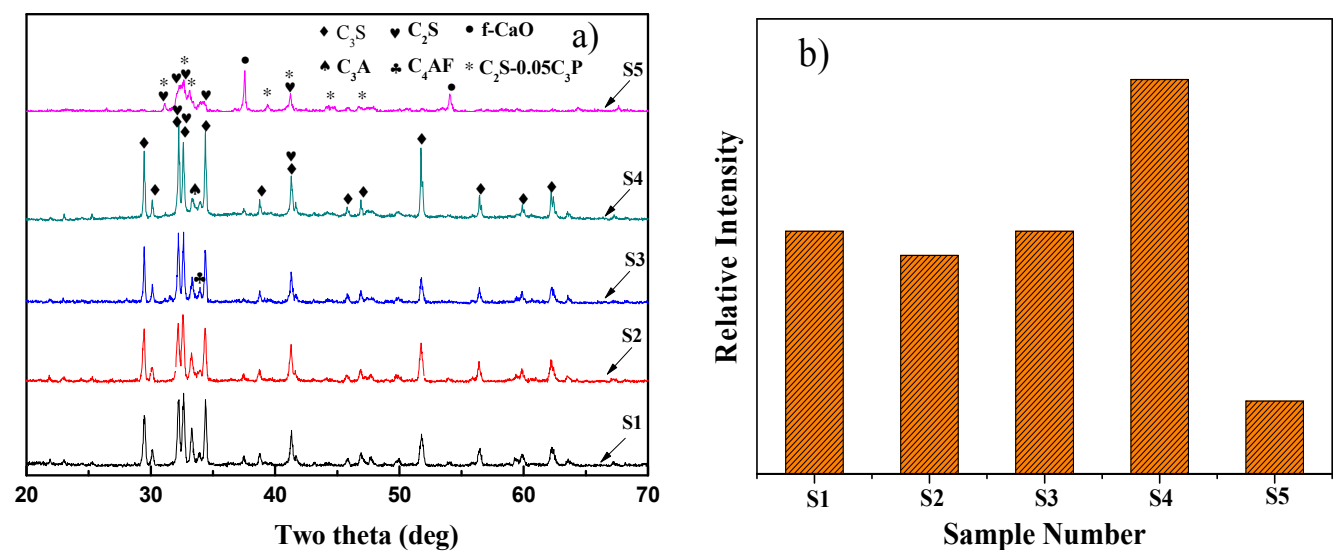

Figure 3. The XRD patterns of the clinker adding with different amount of SS and the peak intensity of $\mathrm{C}_{3} \mathrm{~S}$ : (a) XRD patterns; and (b) comparison of XRD peak intensity at $2 \theta$ range from $31.8^{\circ}$ to $32.4^{\circ}$.

It is also noted that $S S$ addition plays a significant impact on the $C_{3} S$ crystal structure, which is illustrated in Figure S2. For the blank sample S1 without SS addition, the only diffraction peak observed with regard to the crystal structure of $\mathrm{C}_{3} \mathrm{~S}$ is between $51.2^{\circ}$ and $52.2^{\circ}$, indicating a rhombohedral (R) structure $[24,25]$. The split blip between $31.5^{\circ}$ and $33^{\circ}$ indicates the existence of triclinic or monoclinic crystal structure of $\mathrm{C}_{3} \mathrm{~S}$ in blank sample. With the amount of SS additions increasing, the split blip became insignificant and the $\mathrm{C}_{3} \mathrm{~S}$ showed the total rhombohedral structure. With the SS additions up to $15 \mathrm{wt} \%$, the shoulder peak appeared between $31.5^{\circ} \sim 33^{\circ}$ and $51^{\circ} \sim 52.5^{\circ}$, which is characteristic of monoclinic (M) structure. Thus, the $\mathrm{C}_{3} \mathrm{~S}$ polymorphs show transition from rhombohedral to monoclinic structure with increasing amount of SS addition.

To study the differences of crystal characteristics between clinkers with various amounts of SS and CG additions, a comparison of the crystalline phases formed in the clinkers with various additions of SS and CG is presented in Figure 4. In view of the high content of alumina in CG (28.1\%), the maximum amount of CG to be added cannot exceed $10 \mathrm{wt} \%$. It can be seen from Figure $4 \mathrm{a}$ that the major crystalline phases of the clinkers produced by the addition of CG are very similar to that of commercially available Portland cement. With a higher amount CG addition, a more intense peak of $\mathrm{C}_{3} \mathrm{~S}$ was observed, as shown in Figure $4 \mathrm{~b}$, indicating that addition of $C G$ favor $\mathrm{C}_{3} S$ phase formation. Moreover, it is also noteworthy that the intensity of $\mathrm{C}_{3} \mathrm{~S}$ characteristic peak with CG addition was higher than that with SS addition. The results might indicate that addition of CG is more favorable for the formation of $\mathrm{C}_{3} \mathrm{~S}$ in the clinkers compared with SS addition. In addition, as shown in Figure S3, the characteristic diffraction peak between $31.5^{\circ} \sim 33^{\circ}$ and $51^{\circ} \sim 52.5^{\circ}$ show clearly that the structure of $\mathrm{C}_{3} \mathrm{~S}$ was rhombohedral (R), which indicates that addition of $C G$ has very little impact on the $C_{3} S$ crystal structure. 

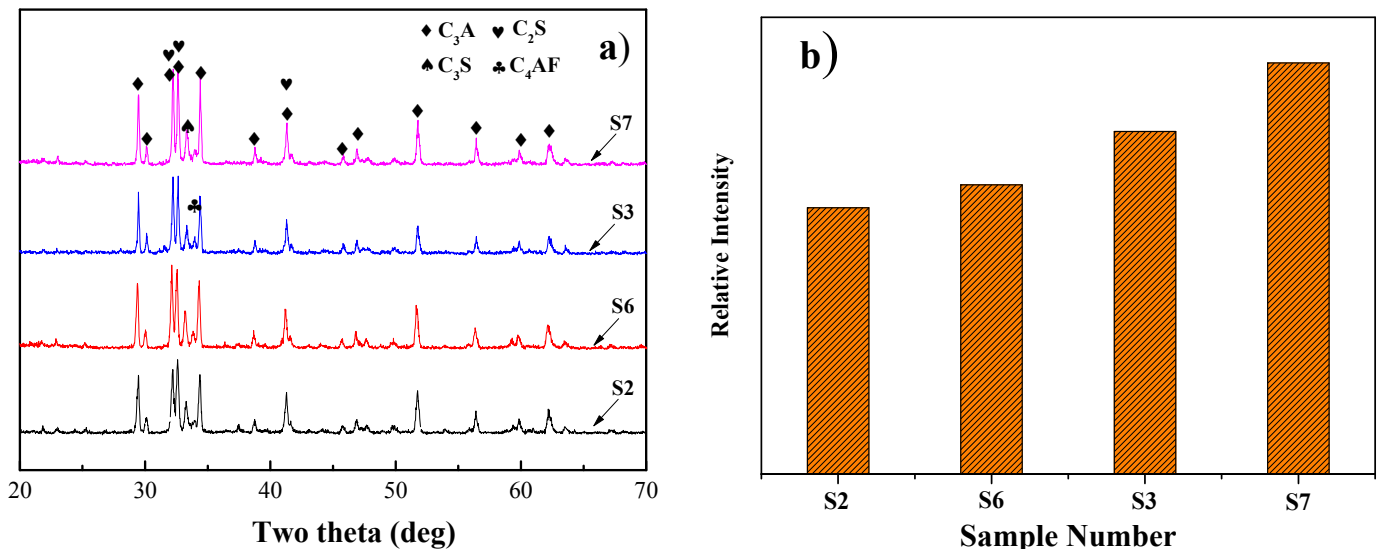

Figure 4. The comparison XRD patterns of the clinker adding with different amount of SS, CG and the peak intensity of $C_{3} S$ : (a) XRD patterns; and (b) comparison of XRD peak intensity at $2 \theta$ from $31.8^{\circ}$ to $32.4^{\circ}$.

Compared to blank sample S1, the positive effect on the $\mathrm{C}_{3} S$ formation with CG addition may be attributed to the special structures of CG. The mineral phase of CG consists mainly of kaolinite, which is weakly bonded with hydroxy group. During the process of calcinations, CG is likely to generate a large amount of active silica and alumina, which can then react with calcium oxide to promote the formation of $\mathrm{C}_{3} \mathrm{~S}$. Meanwhile, the hydroxyl group is also broken, and the released oxygen may attribute to depolymerizing $\mathrm{Si}-\mathrm{O}$ within the raw meals $[26,27]$.

\subsection{Structure Analysis of the Eco-Cement Clinker}

In order to further identify the mechanism of phase generation and the structure transformation, clinkers with different amounts of SS and CG additions were analyzed by FT-IR spectra. The results obtained are shown in Figure 5 and the detail peak assignments are presented in Supplemental Table S1.
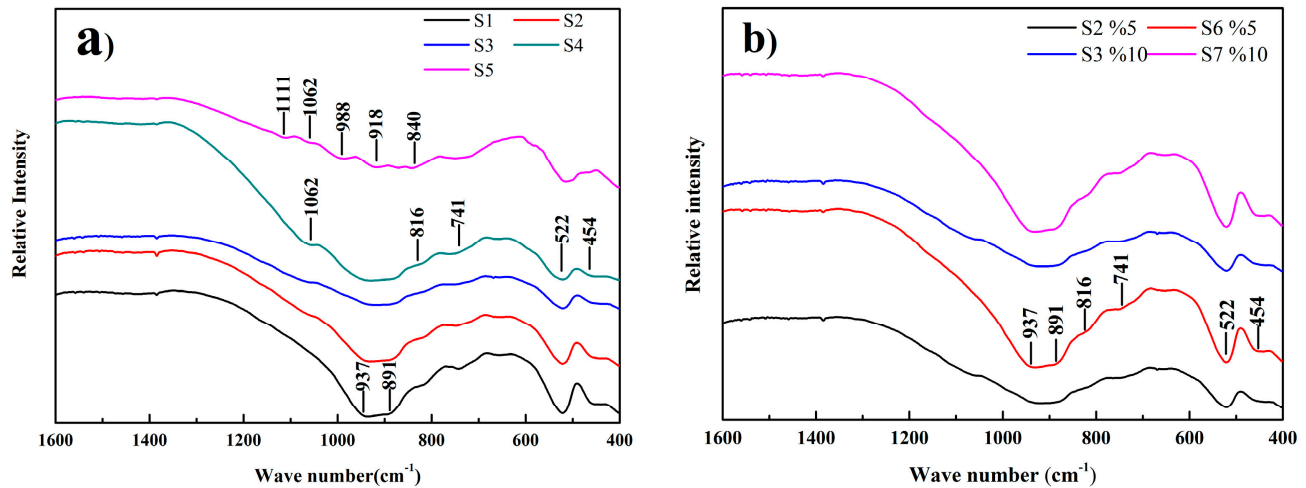

Figure 5. FT-IR spectra for the eco-cement clinkers: (a) clinkers with different amounts of SS additions; and (b) clinkers with different amounts of SS and CG additions.

The most intense peaks at 937 and $891 \mathrm{~cm}^{-1}$ and the shoulder at $816 \mathrm{~cm}^{-1}$ could be attributed to the characteristic of $C_{3} S$ [28]. Meanwhile, the peak at $741 \mathrm{~cm}^{-1}$ can be attributed to the $\mathrm{Al}-\mathrm{O}$ vibrations in $\mathrm{C}_{4} \mathrm{AF}$ while the peak at $454 \mathrm{~cm}^{-1}$ correspond to the Al-O vibration at $\mathrm{C}_{3} \mathrm{~A}$ [29] is indicative of the existence of $\mathrm{C}_{3} \mathrm{~A}$ and $\mathrm{C}_{4} \mathrm{AF}$ in the clinker. For the sample $\mathrm{S} 1$ without $\mathrm{SS}$ addition, the peaks at 937 and $891 \mathrm{~cm}^{-1}$ are separated. With SS addition up to $10 \mathrm{wt} \%$, the two break peaks at 937 and $891 \mathrm{~cm}^{-1}$ merged into a single peak, and the peak at $816 \mathrm{~cm}^{-1}$ became less profound. This indicates that the crystal structure of $C_{3} S$ transformed from a relatively poor symmetry structure to a more symmetrical total rhombohedral structure. The peaks at 937 and $891 \mathrm{~cm}^{-1}$ became more distinct again and the 
peak at $816 \mathrm{~cm}^{-1}$ reappeared as the SS addition was increased to $15 \mathrm{wt} \%$, indicating the appearance of monoclinic structure in $C_{3} S$. Furthermore, the peaks of 937 and $891 \mathrm{~cm}^{-1}$ became more profound, indicating the higher contend of $\mathrm{C}_{3} \mathrm{~S}$ to some extent. With the $\mathrm{SS}$ addition at $30 \mathrm{wt} \%$, the characteristic peaks of the $\mathrm{C}_{3} \mathrm{~S}$ became less intense and the peaks at 988,918 and $840 \mathrm{~cm}^{-1}$ appeared. The three peaks correspond to the $\mathrm{Si}-\mathrm{O}$ vibration of $\mathrm{C}_{2} \mathrm{~S}$ [30]. Besides, the peaks at $1062 \mathrm{~cm}^{-1}$ indicated the existence of $\left(\mathrm{PO}_{4}\right)$ group. The results demonstrate that the decomposition of $\mathrm{C}_{3} \mathrm{~S}$ and the formation of $\mathrm{C}_{2} \mathrm{~S}$ solid solution, which conform to the XRD results (Figure $3 \mathrm{a}$ ).

Figure $5 \mathrm{~b}$ shows the differences between the eco-cement clinkers with simultaneous addition of $\mathrm{SS}$ and CG. It could be seen that the clinkers kept the $\mathrm{C}_{3} S$ structure with $C G$ addition but there were some differences. The intensity of $\mathrm{C}_{3} \mathrm{~S}$ characteristic peaks with $\mathrm{CG}$ addition is more profound than that with SS addition, indicating the formation of $\mathrm{C}_{3} \mathrm{~S}$ with $\mathrm{CG}$ addition. Moreover, the results also show that there has no obvious modification effect on the $C_{3} S$ polymorphs with different amounts of CG addition and its crystal structure is more asymmetric compared to the one with SS addition.

\subsection{Liquid Phase Formation during Clinker Calcination Process}

DSC experiments were conducted to examine the influence of SS and CG additions on the thermal behavior during the clinker formation and the results are shown in Figure 6. It can be seen that the first peak occurred at approximately $785^{\circ} \mathrm{C}$ corresponding to the decomposition of $\mathrm{CaCO}_{3}$ and the second peak appeared at temperature between 1350 and $1400{ }^{\circ} \mathrm{C}$ indicating the formation of liquid phase. The results reveal the fact that addition of SS and CG has no significant effect on the decomposition of $\mathrm{CaCO}_{3}$ but can lower the temperature of liquid phase formation, which can be attributed to the existence of trace elements, such as $\mathrm{Cu}$ and $\mathrm{Zn}$ in the SS and CG (Table 1). The impurities would reduce the melting point of local area melt and favor for the formation of liquid phase during the process of calcinations [31,32]. The chemical reaction between $\mathrm{C}_{2} \mathrm{~S}$ and $\mathrm{CaO}$ could be accelerated with increasing liquid phase. Besides, the elements of magnesium and sulfur introduced by SS or CG can also lower the viscosity of liquid [33]. Therefore, the additions of $S S$ and $C G$ are likely to boost $C_{3} S$ formation and save energy consumption to some extent.

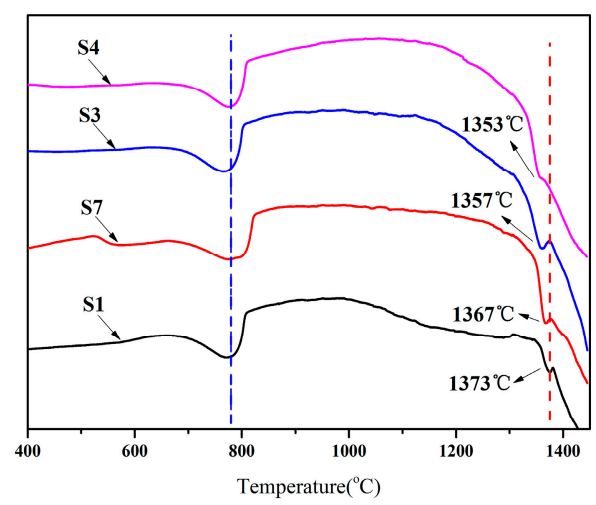

Figure 6. DSC curves for raw meals during heating process.

\subsection{The Immobilization Behavior of Traces Elements}

Trace elements have received more and more attention due to their hazardous effect on human health and ecosystem [34,35]. The concentration of selected trace elements in the ash of SS and the eco-cement clinkers were analyzed and the following equation can be used to describe the immobilized effect of the trace elements [36].

$$
G=\frac{K}{\frac{S}{1-L}}
$$


where $G$ is the immobilization ratio of trace elements; $K$ represents the trace elements concentration in clinker $(\mu \mathrm{g} / \mathrm{g}) ; S$ stands for the trace elements concentration $(\mu \mathrm{g} / \mathrm{g})$ in raw meals; and $L$ is the ignition loss (\%) after burning the raw meals at $1450{ }^{\circ} \mathrm{C}$. Figure 7 illustrates the trace elements immobilization ratio in ash/clinker during the calcinations process of raw SS (samples S4 and S8). Due to the low concentration of Cd in SS and CG, this element could barely be detected in both raw meals as well as clinker. On the other hand, $\mathrm{Pb}$ showed high concentration in raw meals. However, the concentration of lead was found to be below the detection limits in the ash and the clinker, which could be due to the high volatility. Hence, only distribution of $\mathrm{As}, \mathrm{Ba}, \mathrm{Co}, \mathrm{Cr}, \mathrm{Cu}, \mathrm{Ni}$ and $\mathrm{Zn}$ are discussed in this part.

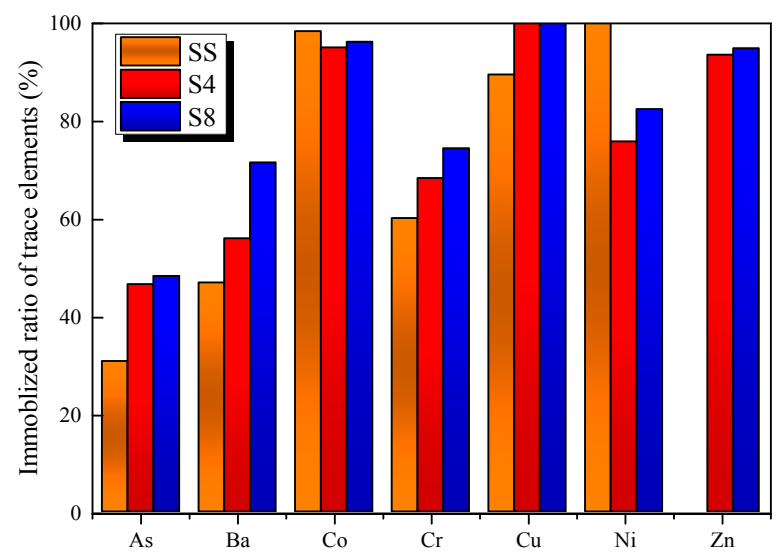

Figure 7. The immobilized ratio of trace elements in ash/clinker during the calcinations process of raw SS, sample S4 and sample S8.

For raw SS, it can be seen that $\mathrm{Co}, \mathrm{Ni}$ and $\mathrm{Cu}$ are non-volatile and are mainly enriched in the ash, while As, $\mathrm{Ba}$ and $\mathrm{Cr}$ are enriched in the ash to different degrees and are classified as semi-volatile elements. Furthermore, it should be noted that $\mathrm{Zn}$ is recognized as a highly volatile element in SS and ended up in the gas phase during the calcination process at $1450{ }^{\circ} \mathrm{C}$. This is consistent with previous study showing that $\mathrm{Zn}$ showed high volatility due to the high content of chlorine in the SS [37]. For sample S4 with $15 \mathrm{wt} \% \mathrm{SS}$ addition, it can be seen that the raw meals do have the immobilization effect with respect to most of the trace elements in SS during the burning process, especially Zn and over $90 \%$ of $\mathrm{Zn}$ can be trapped in the clinker. It is known that the mineral phases in the clinker has a high capacity to immobilize trace elements. $\mathrm{Zn}, \mathrm{As}, \mathrm{Co}, \mathrm{Cu}$ and $\mathrm{Ni}$ can exist in both of interphase and silicate phase while $\mathrm{Cr}$ is preferentially found in the silicate phase [14,38]. Thus, the high retention of $\mathrm{Zn}$ can be ascribed to the formation of oxidic solid solution in the mineral phase of clinker during calcination. This phenomenon was also observed by Barros et al. [39].

In order to immobilize trace elements of the SS in the raw meals to a greater extend and avoid vaporization of volatile elements, SS should be blended with CG as additive into raw meal. The maximum amount of CG addition was recommended as $5 \mathrm{wt} \%$ in consideration of cement clinker modulus, as shown in sample S8. It could be seen that, with the CG addition, immobilization ratio of almost all the trace elements increased as compared with sample S4. The elevated retention effect of trace elements can be attributed to the specific structure of kaolinite. During the calcinations, the crystalline structure of kaolinite is transformed to semi-crystalline metakaolinite and further transformed to mullite. During the reaction series, the decomposition and transition of the crystal structure results in a charge imbalance and the elements may be chemically bonded to the aluminosilicate structure [40]. Therefore, the addition of CG can facilitate the prevention of trace elements emission.

The trace elements incorporated in the clinkers might be leached out under acidic conditions and cause damage to the environment. To investigate this possibility, the toxicity characteristic leaching procedure (TLCP) was conducted to identify the toxicity of the clinker. The regulatory 
threshold values in china are in accordance with GB 5085.3-2007 (identification standards for hazardous wastes-identification for extraction toxicity of China) [9]. Table 3 shows the leaching concentration of toxic elements and the limit of the extraction procedure toxicity standards in china. For the cement clinker with SS addition (sample S4), it can be seen that only Ba and Zn are present in the leachate and none of them exceeded the regulatory thresholds. This indicates the immense immobilization effect of clinker mineral for trace elements. In addition, no big differences on the leaching ability of trace elements could be noticed with the addition of CG into the clinker (sample S8) except for $\mathrm{Zn}$ and $\mathrm{Ba}$. The addition of CG caused a little higher concentration of Ba but lower concentration of $\mathrm{Zn}$ in the leachate. The leaching experiment results show that the eco-cement clinkers are safe to the environment.

Table 3. Toxicity characteristic leaching procedure (TCLP) leaching concentrations (mg/L) of eco-cement clinkers.

\begin{tabular}{cccccccccc}
\hline \multirow{2}{*}{ Sample } & \multicolumn{10}{c}{ Elements (mg/L) } \\
\cline { 2 - 9 } & As & Ba & Cd & Co & Cr & Cu & Ni & Pb & Zn \\
\hline S4 & ND & 1 & ND & ND & ND & ND & ND & ND & 0.06 \\
S8 & ND & 2.13 & ND & ND & ND & ND & ND & ND & ND \\
GB & 5 & 100 & 1 & $\sim$ & 15 & 100 & 5 & 5 & 100 \\
$5085.3-2007$ & & & & & & & & & \\
\hline
\end{tabular}

ND: not detected, $\sim$ : not mentioned in the regulation.

\subsection{Energy and Material Balances with SS and CG Addition}

The previous study indicated that one tonne of Portland cement clinker production need 3-4 GJ primary energy consumptions and 1.6 tonne of raw meals supplement, respectively [41,42]. It could be seen from Table 1 that the calorific value of SS is equivalent to $9.35 \mathrm{GJ} / \mathrm{t}$. According to the present results, $15 \mathrm{wt} \%$ the raw meals could be replaced by SS ( $0.24 \mathrm{t})$, i.e., SS can supply about $2.25 \mathrm{Gt}$ energy during the process of calcinations. Under this condition, the fuel consumption in the manufacture of cement could be reduced by more than $50 \%$ with $15 \mathrm{wt} \% \mathrm{SS}$ addition. Further, for the purpose of immobilizing more trace elements, the blend of SS and CG could be added into raw meals as mentioned above (sample S8). According to the present calculation, about $2.5 \mathrm{Gt}$ energy can be saved, which could reduce the consumption of energy above $60 \%$.

Furthermore, it could also be calculated that incorporation of SS at $15 \mathrm{wt} \%$ in raw meal would result in reducing raw materials requirement of $\mathrm{CaO}$ by approximately $8.1 \mathrm{~kg} / \mathrm{t}$ raw meals, $\mathrm{Al}_{2} \mathrm{O}_{3}$ by $1.1 \mathrm{~kg} / \mathrm{t}$ raw meals, $\mathrm{SiO}_{2}$ by $1.1 \mathrm{~kg} / \mathrm{t}$ raw meals and $\mathrm{Fe}_{2} \mathrm{O}_{3}$ by $0.8 \mathrm{~kg} / \mathrm{t}$ raw meals. The raw meals are traditionally extracted from natural materials including clay, limestone, sand and iron powder. Assuming that using the same nature materials in reference to produce clinker [21], the chemical analyses of the raw materials are shown in the Table S2. Figure 8 illustrates the change of compositions of raw meals made by the nature materials by SS and CG additions. For the raw meals with only SS addition, it can be seen that there will be a significant decrease in the raw materials requirement with $15 \mathrm{wt} \% \mathrm{SS}$ addition, especially for clay. Due to the incorporation of SS, the raw material requirement of limestone would be reduced by $59.2 \mathrm{~kg} / \mathrm{t}$ clinker, clay by $163.2 \mathrm{~kg} / \mathrm{t}$ clinker, sand by $12.8 \mathrm{~kg} / \mathrm{t}$ clinker and $\mathrm{Fe}_{2} \mathrm{O}_{3 \text { (ref) }}$ by $4.8 \mathrm{~kg} / \mathrm{t}$ clinker, i.e., the addition of $\mathrm{SS}$ can replace approximately $4.7 \mathrm{wt} \%$ of limestone, $73.4 \mathrm{wt} \%$ of clay, $14.3 \mathrm{wt} \%$ of sand and $23.1 \mathrm{wt} \%$ of $\mathrm{Fe}_{2} \mathrm{O}_{3(\mathrm{ref})}$. For the raw meals with the blend of SS and CG addition, due to the limit by the modulus of raw meals, the maximum amount of CG addition could only be up to $1.5 \mathrm{wt} \%$ when mixed with $15 \mathrm{wt} \% \mathrm{SS}$. It can be seen that, with the CG addition, there is no significant decrease in the raw materials requirements except the clay, which can be totally replaced. It is admitted that this would lead to a minor increase in the demand for limestone and sand. Therefore, it is important to take into account the costs of raw materials in the cement manufacturing process and determine the most cost-effective raw material proportion. 


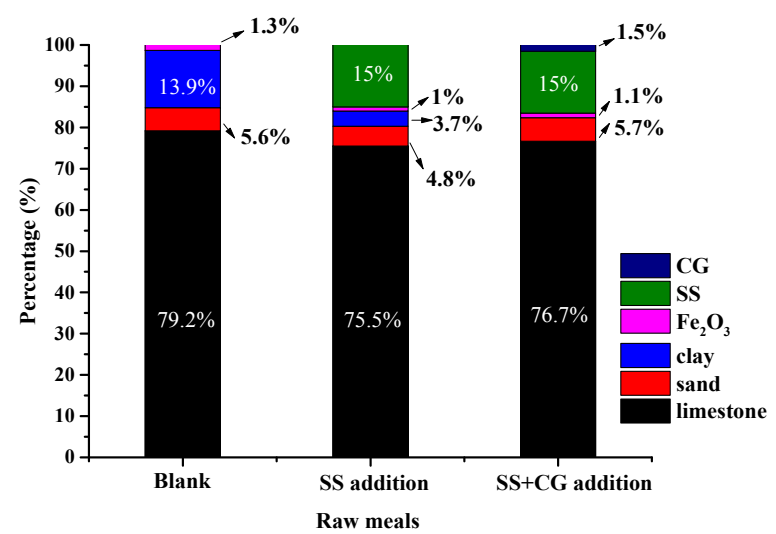

Figure 8. The impact on raw meals compositions with SS or the blend of SS and CG addition.

\section{Conclusions}

The present results clearly demonstrate that sewage sludge and coal gangue can be used successfully as alternative materials and fuel in clinker manufacturing at the laboratory scale. The main conclusions of the work are summarized below:

1. Appropriate $S S$ and $C G$ addition could be beneficial to $C_{3} S$ formation while excess $S S$ addition had the negative effect. The decomposition of $\mathrm{C}_{3} \mathrm{~S}$ into $\mathrm{C}_{2} \mathrm{~S}$ and $\mathrm{f}-\mathrm{CaO}$ was found to occur as the SS addition was increased to $30 \mathrm{wt} \%$ and the amount of SS blending in the raw meals should be strictly controlled. The positive effect of SS and CG additions for $\mathrm{C}_{3} \mathrm{~S}$ formation can be attributed to different mechanisms. The former could be described by introducing a mass of impurities with low melting point, which could lead to decreasing the temperature of liquid phase formation while the special structure of CG could make it easier for the reaction between $\mathrm{f}-\mathrm{CaO}$ and $\mathrm{C}_{2} \mathrm{~S}$. In addition, the raw meals with $C G$ addition could boost more $C_{3} S$ appearance compared with $S S$.

2. SS could lead to the modification of $\mathrm{C}_{3} \mathrm{~S}$ polymorphism from the relatively asymmetric structure to more symmetrical structure $(\mathrm{R})$ with increasing SS addition. As SS addition is increased to $15 \mathrm{wt} \%$, the crystal structure of $\mathrm{C}_{3} \mathrm{~S}$ becomes monoclinic (M).

3. It was found that clinkers had a good effect on immobilizing most of the trace elements in SS, especially Zn. CG can also help stabilize trace elements during the calcinations process. The TCLP results show that the eco-cement clinkers met the standards of the current Chinese regulatory thresholds.

4. Integrated utilization of SS and CG as alternative raw materials and fuel in cement manufacture could effectively reduce raw material and energy consumption. They are expected to reduce energy consumption by more than $60 \%$ as well as reduce a fair amount of the natural raw material consumption according to the present estimation.

Supplementary Materials: The following are available online at www.mdpi.com/1996-1944/9/4/275/s1.

Acknowledgments: This study was sponsored by the National Natural Science Foundation of China (51522401, $51472007,51272005)$, and the Ministry of public welfare industry scientific research projects (201511062).

Author Contributions: Zuotai Zhang and Zhenzhou Yang designed the experiments; Zhenzhou Yang conducted the experiments, analyzed the data, and wrote the manuscript; and Yingyi Zhang, Lili Liu, Seshadri Seetharaman and Xidong Wang advised the experiments and helped editing the manuscript.

Conflicts of Interest: The authors declare no conflict of interest.

\section{References}

1. Hong, J.M.; Xu, C.Q.; Hong, J.L.; Tan, X.F.; Chen, W. Life cycle assessment of sewage sludge co-incineration in a coal-based power station. Waste Manag. 2013, 33, 1843-1852. [CrossRef] [PubMed] 
2. Folgueras, M.B.; Alonso, M.; Diaz, R.M. Influence of sewage sludge treatment on pyrolysis and combustion of dry sludge. Energy 2013, 55, 426-435. [CrossRef]

3. Murakami, T.; Suzuki, Y.; Nagasawa, H.; Yamamoto, T.; Koseki, T.; Hirose, H.; Okamoto, S. Combustion characteristics of sewage sludge in an incineration plant for energy recovery. Fuel Process Technol. 2009, 90, 778-783. [CrossRef]

4. Zhou, H.B.; Ma, C.; Gao, D.; Chen, T.B.; Zheng, G.D.; Chen, J.; Pan, T.H. Application of a recyclable plastic bulking agent for sewage sludge composting. Bioresour. Technol. 2014, 152, 329-336. [CrossRef] [PubMed]

5. Querol, X.; Izquierdo, M.; Monfort, E.; Alvarez, E.; Font, O.; Moreno, T.; Alastuey, A.; Zhuang, X.; Lu, W.; Wang, Y. Environmental characterization of burnt coal gangue banks at Yangquan, Shanxi Province, China. Int. J. Coal Geol. 2008, 75, 93-104. [CrossRef]

6. Zhou, C.C.; Liu, G.J.; Wu, D.; Fang, T.; Wang, R.W.; Fan, X. Mobility behavior and environmental implications of trace elements associated with coal gangue: A case study at the Huainan Coalfield in China. Chemosphere 2014, 95, 193-199.

7. Zhou, C.C.; Liu, G.J.; Yan, Z.C.; Fang, T.; Wang, R.W. Transformation behavior of mineral composition and trace elements during coal gangue combustion. Fuel 2012, 97, 644-650. [CrossRef]

8. Conesa, J.A.; Rey, L.; Egea, S.; Rey, M.D. Pollutant formation and emissions from cement kiln stack using a solid recovered fuel from municipal solid waste. Environ. Sci. Technol. 2011, 45, 5878-5884. [CrossRef] [PubMed]

9. Lin, Y.M.; Zhou, S.Q.; Li, F.Z.; Lin, Y.X. Utilization of municipal sewage sludge as additives for the production of eco-cement. J. Hazard. Mater. 2012, 213, 457-465. [CrossRef] [PubMed]

10. Pavsic, P.; Mladenovic, A.; Mauko, A.; Kramar, S.; Dolenec, M.; Voncina, E.; Vrtac, K.P.; Bukovec, P. Sewage sludge/biomass ash based products for sustainable construction. J. Clean. Prod. 2014, 67, 117-124. [CrossRef]

11. Saikia, N.; Kato, S.; Kojima, T. Production of cement clinkers from municipal solid waste incineration (MSWI) fly ash. Waste Manag. 2007, 27, 1178-1189. [CrossRef] [PubMed]

12. Yen, C.L.; Tseng, D.H.; Lin, T.T. Characterization of eco-cement paste produced from waste sludges. Chemosphere 2011, 84, 220-226. [CrossRef] [PubMed]

13. Taylor, H.F.W. Cement chemistry. In Chemistry for Engineers; Academic Press: London, UK, 1990.

14. Cui, S.P.; Lan, M.Z.; Zhang, J.; Wang, C.Y. Effect and incorporation mechanism of heavy metal elements in hazardous industrial wastes during clinker formation. J. Chin. Ceram. Soc. 2004, 32, 1264-1270.

15. Fan, H.J.; Zhou, H.; Wang, J. Pyrolysis of municipal sewage sludges in a slowly heating and gas sweeping fixed-bed reactor. Energy Convers. Manag. 2014, 88, 1151-1158. [CrossRef]

16. Yang, N.R.; Yue, W.H. The Handbook of Inorganic Matalloid Materials Atlas; Wuhan University of Technology Press: Wuhan, China, 2000. (In Chinese)

17. Zhang, Y.Y.; Nakano, J.; Liu, L.L.; Wang, X.D.; Zhang, Z.T. Trace element partitioning behavior of coal gangue-fired CFB plant: Experimental and equilibrium calculation. Environ. Sci. Pollut. Res. 2015, 22, 15469-15478. [CrossRef] [PubMed]

18. Percival, H.J.; Duncan, J.F.; Foster, P.K. Interpretation of the kaolinite-mullite reaction sequence from infrared absorption spectra. J. Am. Ceram. Soc. 2006, 57, 57-61. [CrossRef]

19. Liu, G.R.; Song, H.J.; Wu, J.H. Thermogravimetric study and kinetic analysis of dried industrial sludge pyrolysis. Waste Manag. 2015, 41, 128-133. [CrossRef] [PubMed]

20. Rodriguez, N.H.; Martinez-Ramirez, S.; Blanco-Varela, M.T.; Donatello, S.; Guillem, M.; Puig, J.; Fos, C.; Larrotcha, E.; Flores, J. The effect of using thermally dried sewage sludge as an alternative fuel on Portland cement clinker production. J. Clean. Prod. 2013, 52, 94-102. [CrossRef]

21. El-Rjoob, A.W.O.; Massadeh, A.M.; Omari, M.N. Evaluation of Pb, Cu, Zn, Cd, Ni and Fe levels in rosmarinus officinalis labaiatae (rosemary) medicinal plant and soils in selected zones in Jordan. Environ. Monit. Assess. 2008, 140, 61-68. [CrossRef] [PubMed]

22. Li, H.X.; Xu, W.; Yang, X.J.; Wu, J.G. Preparation of Portland cement with sugar filter mud as lime-based raw material. J. Clean. Prod. 2014, 66, 107-112. [CrossRef]

23. Xu, W.; Xu, J.C.; Liu, J.; Li, H.X.; Cao, B.; Huang, X.F.; Li, G.M. The utilization of lime-dried sludge as resource for producing cement. J. Clean. Prod. 2014, 83, 286-293. [CrossRef]

24. Bigare, M.; Guinier, A.; Mazieres, C.; Regourd, M.; Yannaqui, N.; Eysel, W.; Hahn, T.; Woermann, E. Polymorphism of tricalcium silicate and its solid solutions. J. Am. Ceram. Soc. 1967, 50, 609-619. [CrossRef] 
25. Urabe, K.; Nakano, H.; Morita, H. Structural modulations in monoclinic tricalcium silicate solid solutions doped with zinc oxide, M(i), M(ii), and M(iii). J. Am. Ceram. Soc. 2002, 85, 423-429. [CrossRef]

26. Horvath, E.; Frost, R.L.; Mako, E.; Kristof, J.; Cseh, T. Thermal treatment of mechanochemically activated kaolinite. Thermochim. Acta 2003, 404, 227-234. [CrossRef]

27. Qiu, G.H.; Luo, Z.Y.; Shi, Z.L.; Ni, M.J. Utilization of coal gangue and copper tailings as clay for cement clinker calcinations. J. Wuhan Univ. Technol. 2011, 26, 1205-1210. [CrossRef]

28. Diouri, A.; Boukhari, A.; Aride, J.; Puertas, F.; Vazquez, T. Stable $\mathrm{Ca}_{3} \mathrm{SiO}_{5}$ solid solution containing manganese and phosphorus. Cem. Concr. Res. 1997, 27, 1203-1212. [CrossRef]

29. Rodriguez, N.H.; Martinez-Ramirez, S.; Blanco-Varela, M.T.; Guillem, M.; Puig, J.; Larrotcha, E.; Flores, J. Evaluation of spray-dried sludge from drinking water treatment plants as a prime material for clinker manufacture. Cem. Concr. Comp. 2011, 33, 267-275. [CrossRef]

30. Elkhadiri, I.; Diouri, A.; Boukhari, A.; Puertas, F.; Vazquez, T. Obtaining a sulfoaluminate belite cement by industrial waste. Mater. Construcc. 2003, 53, 57-69.

31. Kakali, G.; Parissakis, G. Investigation of the effect of Zn oxide on the formation of Portland-cement clinker. Cem. Concr. Res. 1995, 25, 79-85. [CrossRef]

32. Kakali, G.; Parissakis, G.; Bouras, D. A study on the burnability and the phase formation of PC clinker containing Cu oxide. Cem. Concr. Res. 1996, 26, 1473-1478. [CrossRef]

33. Masaki, K.; Maki, I. Effect of prolonged heating at elevated temperatures on the phase composition and textures of Portland cement clinker. Cem. Concr. Res. 2002, 32, 931-934. [CrossRef]

34. Tian, H.Z.; Liu, K.Y.; Zhou, J.R.; Lu, L.; Hao, J.M.; Qiu, P.P.; Gao, J.J.; Zhu, C.Y.; Wang, K.; Hua, S.B. Atmospheric emission inventory of hazardous trace elements from China's coal-fired power plants-temporal trends and spatial variation characteristics. Environ. Sci. Technol. 2014, 48, 3575-3582. [CrossRef] [PubMed]

35. Swaine, D.J. Why trace elements are important. Fuel Process. Technol. 2000, 65, 21-33. [CrossRef]

36. Liu, Y.; Wang, Y.; Wang, L.; Wang, X. Incorporation features of $\mathrm{Cu} \sim(2+), \mathrm{Zn} \sim(2+), \mathrm{Cr} \sim(6+), \mathrm{Cd} \sim(2+)$ and $\mathrm{Pb} \sim(4+)$ ions in cement clinker. In Proceeding of the 8th International Symposium on Cement \& Concrete (ISCC2013), Nanjing, China, 20 September 2013. (In Chinese)

37. Folgueras, A.B.; Diaz, R.A.; Xiberta, J.; Prieto, I. Volatilisation of trace elements for coal-sewage sludge blends during their combustion. Fuel 2003, 82, 1939-1948. [CrossRef]

38. Stephan, D.; Mallmann, R.; Knofel, D.; Hardtl, R. High intakes of Cr, Ni, and Zn in clinker Part I. Influence on burning process and formation of phases. Cem. Concr. Res. 1999, 29, 1949-1957. [CrossRef]

39. Barros, A.M.; Tenorio, J.A.S.; Espinosa, D.C.R. Evaluation of the incorporation ratio of $\mathrm{ZnO}, \mathrm{PbO}$ and $\mathrm{CdO}$ into cement clinker. J. Hazard. Mater. 2004, 112, 71-78. [CrossRef] [PubMed]

40. Li, X.; Li, H.; Yang, G. Promoting the adsorption of metal ions on kaolinite by defect sites: A molecular dynamics study. Sci. Rep. 2015, 5, 14377-14389. [CrossRef] [PubMed]

41. Huntzinger, D.N.; Eatmon, T.D. A life-cycle assessment of Portland cement manufacturing: Comparing the traditional process with alternative technologies. J. Clean. Prod. 2009, 17, 668-675. [CrossRef]

42. Habert, G.; Billard, C.; Rossi, P.; Chen, C.; Roussel, N. Cement production technology improvement compared to factor 4 objectives. Cem. Concr. Res. 2010, 40, 820-826. [CrossRef]

(C) 2016 by the authors; licensee MDPI, Basel, Switzerland. This article is an open access article distributed under the terms and conditions of the Creative Commons by Attribution (CC-BY) license (http://creativecommons.org/licenses/by/4.0/). 